\section{Natural and synthetic antifibrinolytics in adult cardiac surgery: efficacy, effectiveness and efficiency}

Jean-François Hardy MD FRCPC, Sylvain Bélisle MD FRCPC
Epsilon-aminocaproic acid and tranexamic acid, two synthetic antifibrinolytics, and aprotinin, an antifibrinolytic derived from bovine lung, are used to reduce excessive bleeding and transfusion of homologous blood products (HBP) after cardiac surgery. This review analyzes the studies on the utilization of antifibrinolytics in adult cardiac surgery according to the epidemiological concepts of efficacy, effectiveness and efficiency. $A$ majority of published studies confirm the efficacy of antifibrinolytics administered prophylactically to reduce postoperative bleeding and transfusion of HBP. More studies are needed, however, to compare antifibrinolytics and determine if any one is superior to the others. Despite their demonstrated efficacy, antifibrinolytics are only one of the options available to diminish the use of HBP. Other blood-saving techniques, surgical expertise, temperature during cardiopulmonary bypass and respect of established transfusion guidelines may modify the effectiveness of antifibrinolytics to the point where antifibrinolytics may not be necessary. At this time, insufficient data have been published to perform a cost vs benefit analysis of the use of antifibrinolytics. This complex analysis takes into account not only direct costs (cost of the drug and of blood products), but also the ensuing effects of treatment such as: length of stay in the operating room, in the intensive care unit and in the hospital; need for surgical re-exploration; treatment of transfusion or drug-related complications, etc. In particu-

\section{Key words}

BLOOD: antifibrinolytics, aprotinin, 6-aminocaproic acid, tranexamic acid;

SURGERY: cardiovascular, cardiopulmonary bypass.

From the Department of Anesthesia, Montreal Heart Institute, Montréal, Québec, Canada.

Address correspondence to: Dr. Jean-François Hardy, Department of Anesthesia, Montreal Heart Institute, 5000

Belanger Street East, Montreal, Quebec H1T 1C8, Canada. Accepted for publication lst July, 1994. lar, the risk of thrombotic complications associated with antifibrinolytics is the subject of an ongoing, unresolved controversy. In conclusion, it is important for each institution to determine if their patient population (or a subset of this population) is likely to benefit from prophylactic treatment with antifibrinolytics, and to confirm that treatment is not associated with an increased incidence of untoward effects, before engaging in the routine use of any of these medications.

Trois antifibrinolytiques sont présentement utilisés en chirurgie cardiaque afin de réduire le saignement postopératoire et la transfusion de produits sanguins homologues (PSH). Il s'agit de l'acide epsilon-aminocaproïque et de l'acide tranexamique, deux antifibrinolytiques de synthèse, ainsi que de l'aprotinine, un antifibrinolytique naturel isolé à partir de poumons de bovins. Cet article fait une revue de liutilisation des antifibrinolytiques en chirurgie cardiaque de l'adulte en fonction des concepts épidémiologiques fondamentaux que sont l'efficacité expérimentale, l'efficacité clinique et l'efficience. La majorité des études publiées confirme l'efficacité expérimentale des antifibrinolytiques administrés prophylactiquement dans le but de diminuer le saignement postopératoire et la transfusion de PSH. Cependant, les études cherchant à comparer les antifibrinolytiques entre eux sont rares. Seuls d'autres travaux nous permettront d'établir l'efficacité comparée de ces médicaments. Malgré leur efficacité expérimentale, les antifibrinolytiques ne sont quine des options à notre disposition pour diminuer le recours à la transfusion. Ainsi, l'efficacité clinique des antifibrinolytiques sera modifiée par l'utilisation des autres technologies visant à minimiser les pertes sanguines et la transfusion, par l'expertise de léquipe chirurgicale, par la température durant la perfusion extra-corporelle, ainsi que par le respect des indications bien établies de la transfusion. Ainsi, dans un contexte donné, liutilisation de ces médicaments pourra même s'avérer superflue. Nous ne disposons pas actuellement de données suffisantes pour compléter une analyse coûts/ bénéfices des antifibrinolytiques en chirurgie cardiaque de l'adulte. Cette analyse complexe devra tenir compte non seulement des coûts directs (médicaments et produits sanguins), mais aussi 
des effets associés au traitement tels que: durée de séjour en salle d'opération, aux soins intensifs et à lhôpital; nécessité d'une ré-exploration pour hémostase; traitement des complications secondaires aux transfusions ou aux médicaments, etc. Plus spécifiquement, le risque de complications thrombotiques secondaires aux antifibrinolytiques fait l'objet d'une controverse non résolue à ce jour. En conclusion, avant de procéder à l'administration routinière de ces médicaments, chaque institution devra déterminer, dans la population chirurgicale qui lui est propre (ou dans un sous-groupe de cette population), l'utilité et l'innocuité des antifibrinolytiques administrés prophylactiquement.

Excessive bleeding after cardiopulmonary bypass (CPB) has always been a major concern of cardiac anaesthetists and surgeons. In an effort to reduce morbidity associated with transfusion of blood products (transmitted infectious diseases, transfusion reactions, etc.) and to answer concerns that the demand for blood and blood products may exceed the supply, many strategies have been explored to diminish the need for transfusion both during and after CPB. Pharmacological intervention with antifibrinolytics to reduce bleeding associated with $\mathrm{CPB}$ has received much attention recently. ${ }^{1-3}$ It has the main advantages of being readily available and easy to administer, of avoiding the use of expensive equipment, and it may be use prophylactically rather than therapeutically in most instances. Nonetheless, administration of antifibrinolytics entails extra costs to the health care system and clinicians have to be confident that these drugs are not only efficacious, but also effective and efficient. The authors review the available knowledge concerning the use of antifibrinolytics in cardiac surgery from an epidemiological point of view.

The basic purpose of clinical epidemiology is to develop and apply rigorous methodology to clinical observations that will lead to valid clinical conclusions. ${ }^{4}$ Before accepting the conclusions of any article, clinicians must be sure that the three basic principles of epidemiology were respected (adapted from M. Cohen ${ }^{4}$ ). First, the sample chosen must be representative of the population being studied. All persons in the population must have had an equal chance of being chosen. Second, the study was planned so as to minimize systematic and random errors, and the validity of the study must be considered. Systematic error (bias) is that due to all causes other than sampling variability, e.g., error secondary to instrument of measure. Random error (chance) is that due to sampling variability, resulting in characteristics of the sample that are different from those of the population. A high internal validity signifies that the study was well designed and controlled. External validity refers to the general- izability of the results: are they applicable to other situations? If internal validity is high, generalizability is usually low, because conditions of the study are so strict that they apply only to populations identical to those under study.

Third, studies must be classified as efficacy, effectiveness, or efficiency studies. Efficacy studies try to show that intervention $X$ works in an ideal setting, e.g., the typical randomized trial in a major teaching hospital (institution A). Effectiveness studies try to show how intervention $X$ works in the real world. For example, in institution $B$, the systematic use of intervention $Y$ may reduce the beneficial effect of intervention $X$ to the point where intervention $X$ (efficacious in the randomized trial conducted in institution $\mathrm{A}$ ) becomes ineffective. Efficiency studies aim to show what is the best intervention ( $X$, $\mathrm{Y}$, etc.) in terms of cost, personnel, compliance, and the like, given more than one alternative is available. The negative effects of the proposed intervention must be taken into account also when discussing efficiency.

In this article, the authors have analyzed studies on the use of antifibrinolytics in cardiac surgery according to the clinically useful concepts of efficacy, effectiveness and efficiency. While the assumption was made that the studies reviewed respect the first two principles described above, it must be recognized that this premise may not be valid in all cases.

\section{The efficacy of antifibrinolytics in cardiac surgical patients}

A number of drugs have been used to decrease blood loss and the use of blood transfusion after cardiac surgery. Recently there has been a renewed interest in antifibrinolytics, an old class of drugs, whether they be synthetic or natural. Epsilon-aminocaproic acid (EACA) and tranexamic acid (TA), two synthetic antifibrinolytics, and aprotinin (Apt), an antifibrinolytic derived from bovine lung, have been used either to diminish or to prevent excessive bleeding associated with cardiac surgery.

\section{Objectives of treatment}

It must be remembered that the amount of blood shed during and after the operation is only an intermediate outcome. Unfortunately, many studies tend to focus on intermediate outcomes such as bleeding, coagulation profile, platelet count, etc., assuming that any beneficial effect on these will result automatically in a beneficial effect on final outcome. The final outcome to judge the efficacy, effectiveness and efficiency of a drug administered to reduce transfusion is the change in the amount of homologous blood products (HBP) to which patients will be exposed. For example, a drug could produce a small but 
important decrease in blood loss, or a beneficial effect on the bleeding time, but not result in decreased transfusions of HBP. The clinical usefulness of such a drug would be questionable.

\section{Epsilon-aminocaproic acid (Amicar ${ }^{\circledR}$ )}

Epsilon-aminocaproic acid has been used in cardiac surgery since 1964. The conclusions of the earlier studies may not apply in 1994: from 1964 to the mid-seventies, surgery was performed mainly for congenital heart disease, and the equipment used for CPB produced more fibrinolysis than today. Most of the studies from that period were open and/or uncontrolled. ${ }^{2}$

Since 1979, several studies have reported a beneficial effect of EACA to treat ${ }^{5}$ or to prevent ${ }^{6,7}$ postoperative bleeding. The prophylactic administration of EACA by DelRossi $e t$ al. proved efficacious in a study of 350 patients undergoing a variety of surgical procedures. ${ }^{7}$ Blood loss and transfusion of red blood cells decreased in the EACA-treated patients.

Two recent studies demonstrate that EACA may be as efficacious as TA or Apt. Trinh-duc et al. could not show any difference in cumulative postoperative blood loss or in HBP requirements between high-dose Apt and EACA,${ }^{8}$ but this study suffers from the lack of a control group. However, if their conclusions hold true, they might have major financial implications since EACA is much cheaper than high-dose Apt. Postoperative blood loss was reduced similarly by EACA, TA or warm perfusion in a study by Yau $e t$ al. ${ }^{9}$ In this latter study, requirements for HBP were marginally reduced by TA. Thus, a change in perfusion technique (normothermia vs hypothermia) could obviate the need for any antifibrinolytic medication altogether.

Also, the doses of EACA used by DelRossi et al. ${ }^{7}$ (initial dose of $5 \mathrm{~g}$ prior to skin incision, followed by an infusion of $1 \mathrm{~g} \cdot \mathrm{hr}^{-1}$ for the next 6-8 hr) and by Yau et al. ${ }^{9}$ ( $15 \mathrm{~g} i v$ at anaesthetic induction) are small relative to the high doses of the other agents that are now being used. The efficacy of higher doses of EACA has not been investigated.

The promotion of an old drug like EACA is difficult. For fear of thrombotic complications, unsubstantiated by controlled studies, ${ }^{7.8}$ many clinicians will hesitate to administer EACA. Studies with EACA have a feeling of "déjà-vu," are less fashionable, and have little chance of being funded by pharmaceutical companies. On the other hand, the drug is cheap, large-scale clinical studies can be conducted at minimal cost, and introduction into everyday practice is readily feasible.

\section{Tranexamic acid (Cyklokapron ${ }^{\circledR}$ )}

Tranexamic acid is six to ten times more potent than
EACA $^{10}$ and does not suffer from its bad reputation. Identified as an antifibrinolytic in 1964, the prophylactic use of TA to decrease blood loss after CPB was first reported in the late 1980s. Since TA was introduced only recently in cardiac surgery, there are few published reports on its efficacy. Horrow et al. reported that prophylactic TA reduced bleeding after cardiac operations (from 750 to $496 \mathrm{ml}$ ) in a series of 38 patients." A dose of 10 $\mathrm{mg} \cdot \mathrm{kg}^{-1}$ was infused prior to skin incision, followed by an infusion of $1 \mathrm{mg} \cdot \mathrm{kg}^{-1} \cdot \mathrm{hr}^{-1}$ for ten hours. The use of packed red blood cells was similar in both groups, but patients receiving TA required less fresh frozen plasma (FFP). Doubling the dose of TA appears to increase its efficacy. ${ }^{12}$

Even higher doses of TA were employed by Karski et al. ${ }^{13,14} \mathrm{~A}$ retrospective chart review on 411 patients showed that $6 \mathrm{~g}$ of TA are not more efficacious than $10 \mathrm{~g}$ in reducing post-bypass bleeding in the first $24 \mathrm{hr}$ after surgery, but that patients receiving the $10 \mathrm{~g}$ bolus required less red blood cells. ${ }^{13}$ Increasing the dose to $20 \mathrm{~g}$ achieved minimal increase in blood loss reduction in a prospective study in 146 patients. ${ }^{14}$ Transfusion requirements did not differ among groups (TA $10 \mathrm{~g}$ vs 20 $\mathrm{g}$ vs control) due to the effectiveness of autotransfusion in preserving blood loss. ${ }^{14}$ As mentioned previously in a study of 146 patients by Yau et al., ${ }^{9}$ only TA reduced the number of units of packed red blood cells administered to each patient (but not the frequency of platelet, plasma, or cryoprecipitate transfusion) from a mean of three to two units, while postoperative bleeding was reduced similarly by TA, EACA, or warm systemic perfusion $\left(35-37^{\circ} \mathrm{C}\right) .^{9}$ It is worth noting that, in these three studies, $9,13,14$ postoperative bleeding after hypothermic perfusion $\left(25-29^{\circ} \mathrm{C}\right)$ ranged from $1000-1200 \mathrm{ml}$ in the control groups.

The most recent data presented by Karski et al. indicate that $100 \mathrm{mg} \cdot \mathrm{kg}^{-1} \mathrm{TA}$ may be the optimal dose to prevent excessive postoperative blood loss in patients undergoing primary $\mathrm{CPB}$ without systemic cooling. ${ }^{15}$ Of interest, this prospective study on 150 patients did not include a control group and transfusion requirements were not different among the three doses of TA $(50,100$, and $150 \mathrm{mg} \cdot \mathrm{kg}^{-1}$ ).

Thus, at this time, the optimal dose of TA appears to be of the order of $6-10 \mathrm{~g}$, rather than the $1-2 \mathrm{~g}$ dose based on estimates of potency. Even so, it remains to be demonstrated that TA offers an advantage over the older and cheaper drug EACA. The main results of the studies on EACA and TA are summarized in Table I.

\section{Aprotinin (Trasylol ${ }^{\circledR}$ )}

There is little doubt that high (6 million KIU approximately) and intermediate doses ( 2 million KIU in the 
TABLE I Influence of prophylactic EACA or TA on blood losses, percentage of patients transfused, and volume of blood transfused

\begin{tabular}{|c|c|c|c|c|c|}
\hline \multirow{2}{*}{$\frac{\text { Author }}{\text { DelRossi }^{7}}$} & \multirow{2}{*}{$\frac{\text { No. pts }}{350 \dagger}$} & \multicolumn{2}{|c|}{ Postoperative blood loss (ml) } & \multirow{2}{*}{$\begin{array}{l}\begin{array}{l}\% \text { pts } \\
\text { transfused }\end{array} \\
\S \\
\S\end{array}$} & \multirow{2}{*}{$\begin{array}{l}\text { ml or units }(U) \\
R B C \text { transfiused }\end{array}$} \\
\hline & & $\begin{array}{l}\text { EACA }(12 \mathrm{~g}) \\
\mathrm{C}\end{array}$ & $\begin{array}{l}617 \pm 44 \mathrm{ml}^{*} \\
883 \pm 29 \mathrm{ml}\end{array}$ & & \\
\hline Trinh-duc ${ }^{8}$ & 56 & $\begin{array}{l}\text { EACA }(18 \mathrm{~g}) \\
\mathrm{A}\end{array}$ & $\begin{array}{l}978 \mathrm{ml} \# \\
887 \mathrm{ml} \#\end{array}$ & $\begin{array}{l}63 \% \\
38 \%\end{array}$ & $\begin{array}{l}43 \mathrm{U} \text { total } \\
26 \mathrm{U} \text { total }\end{array}$ \\
\hline Yau 9 & $146^{* *} \ddagger$ & $\begin{array}{l}\text { EACA }(15 \mathrm{~g}) \\
\text { TA }(10 \mathrm{~g}) \\
\text { C }\end{array}$ & $\begin{array}{l}881 \pm 64 \mathrm{ml} \\
822 \pm 42^{*} \mathrm{ml} \\
1113 \pm 151 \mathrm{ml}\end{array}$ & $\begin{array}{l}65 \%^{*} \\
49 \%^{*} \\
75 \%\end{array}$ & $\begin{array}{l}2.3 \pm 0.3 \mathrm{U} \\
2.0 \pm 0.2 \mathrm{U}^{*} \\
3.0 \pm 0.6 \mathrm{U}\end{array}$ \\
\hline Horrow" & $38 \dagger$ & $\begin{array}{l}\text { TA }(1.5 \mathrm{~g}) \\
\mathrm{C}\end{array}$ & $\begin{array}{l}496 \pm 228 \mathrm{ml}^{*} \\
750 \pm 314 \mathrm{ml}\end{array}$ & $\begin{array}{l}0 \% \text { (FFP) }^{*} \\
25 \% \text { (FFP) }^{2}\end{array}$ & $\begin{array}{l}275 \pm 241 \mathrm{ml} \\
227 \pm 324 \mathrm{ml}\end{array}$ \\
\hline Karski $^{13}$ & $411^{* * \pm}$ & $\begin{array}{l}\text { TA }(6 \mathrm{~g}) \\
\text { TA }(10 \mathrm{~g}) \\
\text { EACA }(10 \mathrm{~g}) \\
\text { EACA }(15 \mathrm{~g}) \\
\text { C }\end{array}$ & $\begin{array}{l}700 \mathrm{ml}^{* \#} \\
600 \mathrm{ml}^{* \#} \\
700 \mathrm{ml}^{* \#} \\
700 \mathrm{ml}^{* \#} \\
950 \mathrm{ml}^{\circ}\end{array}$ & $\begin{array}{l}45 \% \# \\
35 \% * \# \\
55 \% \# \\
50 \% \# \\
60 \% \#\end{array}$ & $\begin{array}{l}\S \\
\S \\
\S \\
\S \\
\S\end{array}$ \\
\hline
\end{tabular}

$* P<0.05 .{ }^{* *}$ Retrospective study. †Double-blind study. †Non-randomized study. \#Data extracted from figure (approximate). §̧ata not available from the publication.

EACA = epsilon aminocaproic acid (approximate total dose in g); $\mathrm{TA}=$ tranexamic acid (approximate total dose in g); $\mathrm{A}=$ high dose aprotinin; $\mathrm{C}=$ control group; FFP $=$ fresh frozen plasma; $\mathrm{RBC}=$ red blood cells.

CPB prime) are efficacious in reducing blood loss and transfusion requirements after $\mathrm{CPB}$ in adults (Table II). ${ }^{16-29}$ The high-dose regimen recommended in the literature $^{1}$ is based on theoretical considerations and, surprisingly, dose-ranging studies on the efficacy of Apt in clinical practice have never been conducted. Unfortunately, Apt is an expensive drug (see section on efficacy) and its routine administration in cardiac surgery cannot be implemented without a considerable cost to the health care system.

In an effort to reduce costs, two double-blind, randomized, placebo-controlled studies of Apt 1 million KIU have been conducted in which Apt was administered as an infusion ${ }^{30}$ or as a bolus in the oxygenator prime* to patients at high risk of being transfused. ${ }^{31}$ The Apt infusion was ineffective but administration of Apt 1 million $\mathrm{KIU}$ in the CPB prime reduced both the number of patients receiving FFP and the quantity of FFP transfused to each patient. Two reasons may explain the inefficacy or the limited efficacy of Apt in these studies. The dose may have been insufficient but another important reason which may help explain the discrepancies between the results from different centres was that meticulous surgical haemostasis decreased blood loss to a

\section{*Hardy JF, Bélisle S, Perrault J, Carrier M, Robitaille D.} Aprotinin 1 million KIU in the CPB circuit reduces the transfusion of fresh frozen plasma in high risk cardiac surgical patients. Presented at the 15th Annual Meeting of the Society of Cardiovascular Anesthesiologists, April 1993, San Diego, California. level where the efficacy of prophylactic Apt may be difficult to demonstrate.

Similarly, a lack of efficacy of prophylactic high-dose Apt in elective aortocoronary bypass grafting has been reported by Boldt et al. ${ }^{32}$ Blood losses until the first postoperative day in their patients treated by haemofiltration alone during bypass $(390 \pm 230 \mathrm{ml})$ were not different from those in whom high dose Apt and haemofiltration were used $(260 \pm 160 \mathrm{ml}) .{ }^{32}$ It must be noted, however, that the lowest rectal temperature during bypass was 34.1 $\pm 0.5^{\circ} \mathrm{C}$. As in the study by Yau et al. on the effect of warm surgery, EACA and TA on postoperative bleeding, ${ }^{9}$ the influence of temperature during CPB may be important to the point where the beneficial effects of high doses of Apt on platelet function, postoperative blood losses and transfusion of HBP are negated by normothermic CPB (nasopharyngeal temperature $>34^{\circ} \mathrm{C}$ ). ${ }^{33}$ These three recent studies ${ }^{9,32,33}$ emphasize the importance of considering perfusion temperature when evaluating the efficacy of antifibrinolytics.

Aspirin therapy is associated with increased bleeding and transfusion requirements and more frequent surgical reexploration after coronary artery bypass surgery. Nonetheless, several surgeons will hesitate to interrupt aspirin therapy before the operation, for fear of reactivating anginal symptoms. In these circumstances, high-dose Apt decreases both blood loss and prevalence of transfusion. ${ }^{34,35}$ However, low-dose Apt (2 million KIU in the pump prime) or TA ( $10 \mathrm{~g} \dot{\boldsymbol{N}}$ prior to skin incision) may be as efficacious as high-dose Apt. ${ }^{36}$

Studies comparing Apt with synthetic antifibrinolytics 
TABLE II Influence of prophylactic aprotinin on blood losses, percentage of patients transfused, and volume of blood transfused

\begin{tabular}{|c|c|c|c|c|c|}
\hline \multirow{3}{*}{$\frac{\text { Author }}{\text { Royston }^{16}}$} & \multirow{3}{*}{$\frac{\text { No. } p t s}{22^{*}}$} & \multicolumn{2}{|c|}{$\begin{array}{l}\text { Pastoperative blood loss } \\
\mathrm{ml} \text { or } \mathrm{g} \text { of haemoglobin }\end{array}$} & \multirow{3}{*}{$\begin{array}{l}\begin{array}{l}\% \text { pts } \\
\text { transfused }\end{array} \\
36 \% \\
100 \%\end{array}$} & \multirow{3}{*}{$\begin{array}{l}\text { ml or units }(U) \\
R B C \text { transfused } \\
\S \\
\S\end{array}$} \\
\hline & & A & $286 \pm 48 \mathrm{ml}$ & & \\
\hline & & & $1509 \pm 388 \mathrm{ml}$ & & \\
\hline \multirow[t]{2}{*}{ van Oeveren ${ }^{17}$} & 22 & $\mathrm{~A}$ & $357 \mathrm{ml}$ & $\S$ & $\S$ \\
\hline & & C & $674 \mathrm{ml}$ & $\S$ & $\S$ \\
\hline \multirow[t]{2}{*}{ Alajmo $^{18}$} & 34 & A & $486 \pm 47 \mathrm{ml}$ & $\S$ & $213 \pm 85 \mathrm{ml}$ \\
\hline & & $\mathrm{C}$ & $830 \pm 117 \mathrm{ml}$ & $\S$ & $409 \pm 140 \mathrm{ml}$ \\
\hline \multirow[t]{2}{*}{ Bidstrup ${ }^{19}$} & $80 \dagger$ & A & $309 \pm 133 \mathrm{ml}$ & $20 \%$ & $\S$ \\
\hline & & $\mathrm{C}$ & $573 \pm 166 \mathrm{ml}$ & $95 \%$ & $\S$ \\
\hline \multirow[t]{2}{*}{ Dietrich $^{20}$} & $152 \ddagger$ & A & $761 \pm 51 \mathrm{ml}$ & $58 \%$ & $1015 \pm 113 \mathrm{ml}$ \\
\hline & 3179 & $\mathrm{C}$ & $1070 \pm 43 \mathrm{ml}$ & $82 \%$ & $1783 \pm 100 \mathrm{ml}$ \\
\hline \multirow[t]{2}{*}{ Fraedrich ${ }^{21}$} & $80 \dagger$ & A & $652 \pm 382 \mathrm{ml}$ & $\S$ & $242 \pm 359 \mathrm{ml}$ \\
\hline & & $\mathrm{C}$ & $1204 \pm 705 \mathrm{ml}$ & $\S$ & $937 \pm 843 \mathrm{ml}$ \\
\hline \multirow[t]{2}{*}{ Wildevuur ${ }^{22}$} & $28 \dagger$ & $\mathbf{a}$ & $14 \pm 3 \mathrm{~g}$ & $\S$ & $\S$ \\
\hline & & $\mathrm{C}$ & $64 \pm 6 g$ & $\S$ & $\S$ \\
\hline \multirow[t]{2}{*}{ Dietrich $^{23}$} & $40 \dagger$ & A & $738 \pm 411 \mathrm{ml}$ & $37 \%$ & $163 \pm 308 \mathrm{ml}$ \\
\hline & & C & $1431 \pm 760 \mathrm{ml}$ & $75 \%$ & $838 \pm 963 \mathrm{ml}$ \\
\hline \multirow[t]{3}{*}{ van Oeveren ${ }^{24}$} & $60 \dagger$ & A & $17 \pm 9 \mathrm{~g}$ & $38 \%$ & $\S$ \\
\hline & & $\mathrm{C}$ & $37 \pm 12 \mathrm{~g}$ & $68 \%$ & $\S$ \\
\hline & & a & $19 \pm 9 g$ & $38 \%$ & $\S$ \\
\hline \multirow[t]{2}{*}{ Blauhut $^{25}$} & $26 \ddagger$ & A & $\S$ & $15 \%$ & $\S$ \\
\hline & & $\mathrm{C}$ & $\S$ & $62 \%$ & $\S$ \\
\hline \multirow[t]{2}{*}{ Harder $^{26}$} & $80 \dagger$ & A & $559 \pm 109 \mathrm{ml}$ & $31.5 \%$ & $\S$ \\
\hline & & C & $911 \pm 170 \mathrm{ml}$ & $57.2 \%$ & $\S$ \\
\hline \multirow[t]{2}{*}{ Havel $\left.\right|^{27}$} & 22 & A & $610 \pm 310 \mathrm{ml}$ & $\S$ & $\S$ \\
\hline & & $\mathrm{C}$ & $1000 \pm 440 \mathrm{ml}$ & $\S$ & $\S$ \\
\hline \multirow[t]{2}{*}{ Carrel $^{28}$} & $23 \dagger$ & $\mathbf{a}$ & $430 \pm 130 \mathrm{ml}$ & $\S$ & $205 \pm 125 \mathrm{ml}$ \\
\hline & 30 & $\mathrm{C}$ & $915 \pm 270 \mathrm{ml}$ & $\S$ & $880 \pm 220 \mathrm{ml}$ \\
\hline \multirow[t]{4}{*}{ Schonberger ${ }^{29}$} & $200^{* *}$ & A & $684 \pm 57 \mathrm{ml}(\mathrm{IMA})$ & $22 \%$ & $0.5 \pm 0.2 \mathrm{U}$ \\
\hline & & A & $1055 \pm 80 \mathrm{ml}(\mathrm{BIMA})$ & $22 \%$ & $0.6 \pm 0.2 \mathrm{U}$ \\
\hline & & C & $1237 \pm 93 \mathrm{ml}($ IMA) & $58 \%$ & $1.6 \pm 0.3 \mathrm{U}$ \\
\hline & & $\mathrm{C}$ & $1404 \pm 135 \mathrm{ml}$ (BIMA) & $52 \%$ & $2.5 \pm 0.7 \mathrm{U}$ \\
\hline
\end{tabular}

*Reoperations. **Retrospective study. †Double-blind study. $\Varangle$ Non-randomized study. $\$ D$ ata not available from the publication. $\uparrow$ Historic controls. IMA = unilateral internal mammary artery bypass grafting; BIMA = bilateral IMA; RBC $=$ red blood cells; $A=$ high-dose aprotinin; $\mathrm{C}=$ control group; $\mathrm{a}=2$ million KIU in cardiopulmonary bypass prime only. Blood losses were significantly reduced by $A$ or a when compared to $C$.

(Adapted from Hardy JF, Desroches J. Natural and synthetic antifibrinolytics in cardiac surgery, Can J Anaesth 1992; 39: 353-65).

have begun to appear recently. Apart from the published study by Trinh-duc et al. comparing high doses of Apt with EACA that was discussed previously, ${ }^{8}$ a few other comparative studies have been published in abstract form. Isetta et al. compared Apt with TA in 108 patients undergoing CPB ${ }^{37}$ Infusion of intermediate doses of Apt $(500,000 \mathrm{KIU}$ after induction, followed by an infusion of $500,000 \mathrm{KIU} \cdot \mathrm{hr}^{-1}$ until the end of CPB) did not offer any advantage over low-dose TA (15 mg $\mathrm{kg}^{-1}$ before the injection of heparin prior to CPB and $15 \mathrm{mg} \cdot \mathrm{kg}^{-1}$ after injection of protamine). Both treatments reduced blood loss and transfusions. Hamilton et al. compared high-dose Apt with TA $10 \mathrm{~g} i v$ prior to skin incision in 24 patients undergoing repeat open heart surgery. ${ }^{38}$ Chest tube drainage and transfusion requirements were similar in both groups. Murkin compared blood loss and requirements for red blood cells in patients undergoing repeat sternotomy who received either high-dose Apt, low-dose Apt (2 million KIU in the pump prime), or TA (10 g $i v$ prior to skin incision) ${ }^{39} \mathrm{He}$ concluded that high-dose Apt and TA were equally effective in this patient population whereas low-dose Apt did not prove to be beneficial. It remains unclear why low-dose Apt was not efficacious in reoperative procedures ${ }^{39}$ but of benefit in aspirin-treated patients. ${ }^{36}$

Unfortunately, as in the report by Trinh-duc et al. ${ }^{8}$ the studies by Hamilton ${ }^{38}$ and by Murkin ${ }^{36,39}$ suffer from the lack of a control group. Another major limitation of these studies ${ }^{36-39}$ is the small number of patients enrolled. Given the inherent and important variability of postoperative blood loss and of transfusion requirements, considerably more patients will be required before the 
results of similar studies can be interpreted with an acceptable degree of confidence.

Thus, in general, high doses of Apt (6 million KIU) are efficacious. Very low doses (1 million KIU) may not suffice, especially if bleeding is already low. Overall, intermediate doses ( 2 million KIU in the pump prime) have proved to be as effective as the high-dose regimen (Table II). Finally, a different and interesting approach to the use of Apt in open heart operations has been proposed by Tatar et al ${ }^{40}$ Topical application of Apt 1 million $\mathrm{KIU}$ in the pericardial cavity reduces postoperative chest drainage and transfusion of HBP. The advantages of this approach include the use of a small, relatively inexpensive dose and, possibly, the lack of systemic effect since Apt could not be detected in the patients' blood.

\section{Should we be using these drugs, i.e., are antifibrinolytics effective?}

As one can see from the previous discussion of the efficacy of antifibrinolytics to decrease blood loss and transfusion requirements in cardiac surgical patients, there is no simple answer to this question. Studies from different centres have produced a sum of data that tend to demonstrate that drugs administered prophylactically will reduce excessive bleeding effectively in the first $24 \mathrm{hr}$ after cardiac surgery. Excessive bleeding could, tentatively, be defined as chest drainage of $>600-800 \mathrm{ml}$. At the present time, there is no definitive data to prove that any one of the available antifibrinolytics (EACA, TA, or Apt) is superior to the others in this respect.

As for the reduction of transfusion, it is less clear if pharmacological treatment is effective. This lack of effect may result, in part, from suboptimal transfusion habits. Excessive and inappropriate transfusion in a number of American hospitals has been shown to result from noncompliance with national consensus recommendations. ${ }^{41}$ Application of these recommendations at the institutional level should result in decreases of perioperative blood component use, and should be implemented before pharmacological prophylaxis.

Exposure to HBP was determined in relationship to postoperative chest drainage in 3022 patients from the data bank of the Department of Anesthesia of the Montreal Heart Institute. The figure shows that patients bleeding up to $1000 \mathrm{ml}$ after CPB receive an average of six units of HBP or less during their hospital stay. These patients represent $72 \%$ of the total population (2188/ 3022). As postoperative bleeding increases $>1000 \mathrm{ml}$, the number of units transfused also increases. It is conceivable that the first group of patients could be managed conservatively by methods such as predonation of autologous blood, reinfusion of shed mediastinal blood and intraoperative autotransfusion. On the other hand, the

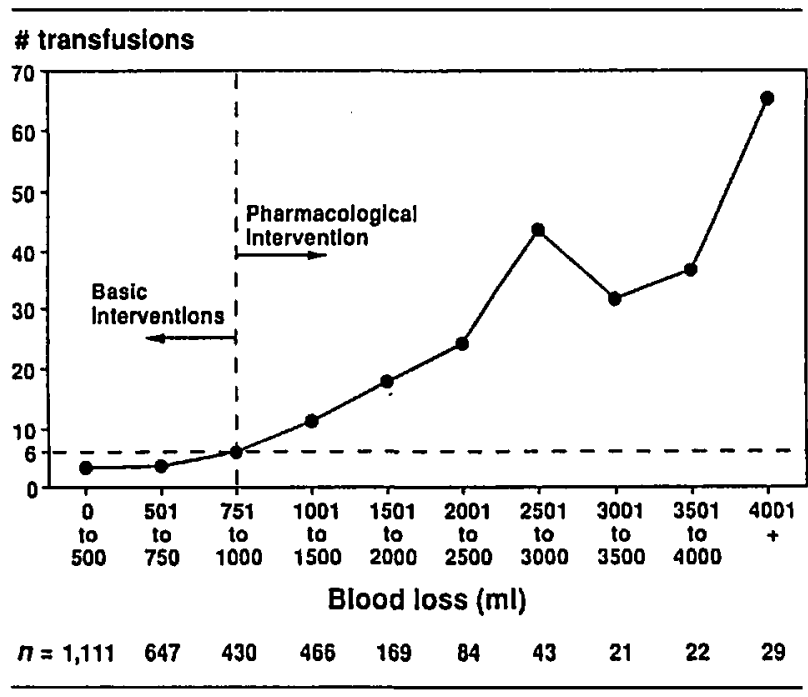

FIGURE Mean exposure to homologous blood products (units) as a function of postoperative mediastinal drainage, from 3032 adult cardiac operations performed with cardiopulmonary bypass at the Montreal Heart Institute in 1991 and 1992. Patients bleeding $\leq 1000 \mathrm{ml}$ were exposed to fewer than six units on average.

$28 \%$ of patients likely to receive $>$ six units of HBP would probably benefit the most from pharmacological prophylaxis. While this approach suggests that patients undergoing cardiac surgery may be subdivided into two groups according to postoperative bleeding and the use of blood products, there remains to be found a method (laboratory, demographic or other) of identifying to which group a given patient belongs before surgery.

\section{Cost vs benefit analysis (efficiency)}

This is a complex issue that takes into account not only direct costs (cost of the drug and of blood products), but also the ensuing effects of the treatment such as: length of stay in the operating room, in the intensive care unit and in the hospital, need for surgical re-exploration, treatment of transfusion or drug-related complications, etc.

The issue of cost is especially relevant with Apt, an expensive drug. At the present time, the cost of highdose Apt (6 million KIU) treatment is approximately $\$ 930 / \mathrm{CDN}$ (a vial of $500,000 \mathrm{KIU}$ costs $\$ 77.50 \mathrm{CDN}$ at our institution). Routine use of Apt alone would entail an expense of more than $2.5 \%$ of the annual budget of the Montreal Heart Institute. On the other hand, drugs like EACA and TA are relatively inexpensive and could be used extensively, with less impact on the hospital's budget. The prophylactic administration of synthetic antifibrinolytics requires up to $20 \mathrm{~g}$ of EACA or $10 \mathrm{~g} i \mathrm{v}$ of TA which costs $\$ 89 \mathrm{CDN}$ and $\$ 247 \mathrm{CDN}$ per patient respectively. If proved effective at the institutional level, the use of intermediate ( 2 million KIU in the CPB prime) 
or low ( 1 million KIU in the pericardial cavity) doses of Apt would be competitive from an economic standpoint.

Based on economic concerns alone, it appears illogical to administer an expensive drug like Apt (6 million KIU) to low-risk primary procedures, when less expensive alternatives (such as retransfusion of shed mediastinal blood) have already demonstrated their efficacy. Also, in first-time procedures, the beneficial effect of the drug on consumption of blood products is likely to be small when surgical blood loss is already minimal ${ }^{31,32}$ and/or when transfusion practice does not follow established guidelines. Application of these guidelines should result in considerable decreases of perioperative blood component use and reduce costs.

Reduced operating times, less need for work after regular hours, and shorter stays in the intensive care unit may still justify the short-term cost of a drug like Apt. However, the appropriate data must become available to substantiate a beneficial effect of the drug on these variables. Similarly, data demonstrating the beneficial effect of Apt on transfusion-related complications must also become available to justify the cost of the drug in the long term. While the initial low cost of synthetic antifibrinolytics is attractive, ${ }^{38}$ data on the financial consequences of potential side effects must ensure that these do not outweigh the initial economies.

Finally, while antifibrinolytics may be useful, manipulation of haemostasis is a two-edged sword. The risk of thrombotic complications is controversial, probably small, but exists. Thrombotic complications affecting cerebral, cardiac or renal function will cause severe morbidity, if not mortality, to the patient and entail considerable expense for the health care system. Two recent studies suggest that, under certain circumstances, the use of $\mathrm{Apt}^{42}$ or $\mathrm{TA}^{43}$ may be associated with an increased incidence of postoperative myocardial infarction, but both studies failed to achieve statistical significance. Still, these results are of concern because they indicate that use of antifibrinolytics may be associated with deleterious effects on the myocardium when anticoagulation is inadequate ${ }^{44}$ (as in the study by Cosgrove et al. ${ }^{42}$ ) or when the drug is used routinely after, rather than before, CPB (as in the study by Ovrum et al. ${ }^{43}$ ). Also, use of Apt in elderly patients undergoing operations on the thoracic or thoracoabdominal aorta using CPB and profound hypothermic circulatory arrest is associated with an increased risk of postoperative renal dysfunction and failure, and of death. ${ }^{45}$. On the other hand, in a magnetic resonance imaging study examining saphenous vein graft patency after aortocoronary bypass grafting, Bidstrup et al. failed to demonstrate an adverse effect of Apt in patients undergoing first-time myocardial revascularization. ${ }^{46}$ Similarly, an adverse effect of Apt on early vein graft patency rates was not demonstrated in a study of 216 patients assessed by ultrafast computed tomography, ${ }^{47}$ or in a study of 45 patients undergoing coronary angiography after coronary bypass operation. ${ }^{48}$ Data on the safety and efficacy of Apt therapy in 41 cardiac centres in the United Kingdom show that the use of Apt in cardiac surgical patients at high risk for excessive bleeding is associated with a low incidence of adverse events. ${ }^{49}$ It remains to be demonstrated whether topical application of Apt (or synthetic antifibrinolytics) will avoid thrombotic complications completely.

Again, the inappropriate use of potent drugs like antifibrinolytics is likely to be associated with major complications. More studies are required to define exactly which patients should receive which drug, at what dosage and under what conditions. Failure to respect the limits of drug usage established by these studies risks swinging the pendulum from generalized, routine use of antifibrinolytics to overt rejection of a useful therapeutic modality for fear of (unwarranted) complications.

\section{Conclusion}

A majority of published studies confirms the efficacy of antifibrinolytics administered prophylactically to reduce postoperative bleeding and transfusion of HBP. More studies are needed to compare antifibrinolytics and determine if any drug is superior. Despite their proved efficacy, antifibrinolytics are only one of the options available to reduce the use of $\mathrm{HBP}{ }^{50}$ The expertise of the surgeon, normothermic CPB and strict adherence to established transfusion guidelines may blunt the effectiveness of antifibrinolytics to the point where antifibrinolytics may not be necessary. Under certain circumstances, manipulation of haemostasis may be associated with complications. It is important therefore for each institution to determine if their patient population (or a subset of this population) is likely to benefit from prophylactic treatment with antifibrinolytics, and to confirm that treatment is not associated with an increased incidence of untoward effects, before engaging in the routine use of any of these medications.

\section{References}

1 Royston D. High-dose aprotinin therapy: a review of the first five years' experience. J Cardiothorac Vasc Anesth 1992; 6: 76-100.

2 Hardy J-F, Desroches $J$. Natural and synthetic antifibrinolytics in cardiac surgery. Can J Anaesth 1992; 39: 353-65.

3 Westaby $S$. Aprotinin in perspective. Ann Thorac Surg 1993; 55: 1033-41.

4 Cohen $M M$. Using epidemiology to study adverse out- 
comes in anaesthesia. Can J Anaesth 1990; 37: SxlvSxlviii.

5 Lambert CJ, Marengo-Rowe AJ, Leveson JE, et al. The treatment of postperfusion bleeding using $\epsilon$-aminocaproic acid, cryoprecipitate, fresh-frozen plasma, and protamine sulfate. Ann Thorac Surg 1979; 28: 440-4.

6 Vander Salm TJ, Ansell JE, Okike ON, et al. The role of epsilon-aminocaproic acid in reducing bleeding after cardiac operation: a double-blind randomized study. J Thorac Cardiovasc Surg 1988; 95: 538-40.

7 DelRossi AJ, Cernaianu AC, Botros S, Lemole GM, Moore $R$. Prophylactic treatment of postperfusion bleeding using EACA. Chest 1989; 96: 27-30.

8 Trinh-duc P, Wintrebert $P$, Boulfroy $D$, Albat $B$, Thévenet $A$, Roquefeuil $B$. Comparaison des effets de l'acide $\epsilon-$ aminocaproïque et de l'aprotinine sur le saignement per- et post-opératoire en chirurgie cardiaque. Ann Chir 1992; 46: 677-83.

9 Yau TM, Carson S, Weisel RD, et al. The effect of warm heart surgery on postoperative bleeding. J Thorac Cardiovasc Surg 1992; 103: 1155-63.

10 Verstraete $M$. Clinical application of inhibitors of fibrinoly sis. Drugs 1985; 29: 236-61.

11 Horrow JC, Hlovacek J, Strong MD, et al. Prophylactic tranexamic acid decreases bleeding after cardiac operations. J Thorac Cardiovasc Surg 1990; 99: 70-4.

12 Horrow J, Van Riper D, Parmet J, Whooley P. What dose of tranexamic acid is optimally hemostatic? Anesthesiology 1991; 75: A986.

13 Karski JM, Teasdale SJ, Norman PH, Carroll JA, Weisel $R D$, Glynn MFX. Prevention of postbypass bleeding with tranexamic acid and $\epsilon$-aminocaproic acid. J Cardiothorac Vasc Anesth 1993; 7: 431-5.

14 Karski JM, Teasdale SJ, Norman P, et al. Reduction of post cardiopulmonary bypass bleeding with tranexamic acid. Can J Anaesth 1992; 39: A139.

15 Karski JM, Joiner R, Carroll J, et al. Comparison of the effect of 3 different doses of tranexamic acid on postoperative bleeding in cardiac surgery performed without active systemic cooling. Can J Anaesth 1994; 41 : A41.

16 Royston D, Bidstrup BP, Taylor KM, Sapsford RN. Effect of aprotinin on need for blood transfusion after repeat open-heart surgery. Lancet 1987; II: 1289-91.

17 van Oeveren W, Jansen NJG, Bidstrup BP, et al. Effects of aprotinin on hemostatic mechanisms during cardiopulmonary bypass. Ann Thorac Surg 1987; 44: 640-5.

18 Alajmo F, Calamai G, Perna AM, et al. High-dose aprotinin: hemostatic effects in open heart operations. Ann Thorac Surg 1989; 48: 536-9.

19 Bidstrup BP, Royston D, Sapsford RN, Taylor KM. Reduction in blood loss and blood use after cardiopulmonary bypass with high dose aprotinin (Trasylol). J Thorac Cardiovasc Surg 1989; 97: 364-72.
20 Dietrich $W$, Barankay A, Dilthey $G$, et al. Reduction of homologous blood requirement in cardiac surgery by intraoperative aprotinin application - clinical experience in 152 cardiac surgical patients. Thorac Candiovasc Surgeon 1989; 37: 92-8.

21 Fraedrich G, Weber C, Bernard C, Hettwer A, Schlosser V. Reduction of blood transfusion requirement in open heart surgery by administration of high doses of aprotinin - preliminary results. Thorac Cardiovasc Surgeon 1989; 37: 89-91.

22 Wildevuur Ch RH, Eijsman L, Roozendaal KJ, Harder $M P$, Chang $M$, van Oeveren $W$. Platelet preservation during cardiopulmonary bypass with aprotinin. Eur J Cardiothorac Surg 1989; 3: 533-8.

23 Dietrich $W$, Spannagl $M$, Jochum $M$, et al. Influence of high-dose aprotinin treatment on blood loss and coagulation patterns in patients undergoing myocardial revascularization. Anesthesiology 1990; 73: 1119-26.

24 van Oeveren W, Harder MP, Roozendaal KJ, Eijsman $L$, Wildevuur $C R H$. Aprotinin protects platelets against the initial effect of cardiopulmonary bypass. $\mathbf{J}$ Thorac Cardiovasc Surg 1990; 99: 788-97.

25 Blauhut B, Gross $C$, Necek S, Doran JE, Späth P, Lundsgaard-Hansen $P$. Effects of high-dose aprotinin on blood loss, platelet function, fibrinolysis, complement, and renal function after cardiopulmonary bypass. J Thorac Cardiovasc Surg 1991; 101: 958-67.

26 Harder MP, Eijsman $L$, Roozendaal KJ, van Oeveren $W$, Wildevuur $C R H$. Aprotinin reduces intraoperative and postoperative blood loss in membrane oxygenator cardiopulmonary bypass. Ann Thorac Surg 1991; 51: 936-41.

27 Havel $M$, Teufelsbauer $H$, Knöbl P, et al. Effect of intraoperative aprotinin administration on postoperative bleeding in patients undergoing cardiopulmonary bypass operation. J Thorac Cardiovasc Surg 1991; 101: 968-72.

28 Carrel T, Bauer E, Laske A, von Segesser L, Turina M. Low-dose aprotinin also allows reduction of blood loss after cardiopulmonary bypass (Letter). J Thorac Cardiovasc Surg 1991; 102: 801.

29 Schönberger JPAM, Everts PAM, Ercan $H$, et al. Lowdose aprotinin in internal mammary artery bypass operations contributes to important blood saving. Ann Thorac Surg 1992; 54: 1172-6.

30 Hardy J-F, Desroches J, Bélisle S, Perrault J, Carrier $M$, Robitaille $D$. Low dose aprotinin infusion is not clinically useful to reduce bleeding and transfusion of homologous blood products in high-risk cardiac surgical patients. Can J Anaesth 1993; 40: 625-31.

31 Hardy J-F, Perrault J, Tremblay N, Robitaille D, Blain R, Carrier $M$. The stratification of cardiac surgical procedures according to use of blood products: a retrospective analysis of 1480 cases. Can J Anaesth 1991; 38: 511-7. 
32 Boldt J, Zickmann B, Czeke A, Herold C, Dapper F, Hempelmann $G$. Blood conservation techniques and platelet function in cardiac surgery. Anesthesiology 1991; 75 : 426-32.

33 Boldt J, Knothe C, Zickmann B, Bill S, Dapper F, Hempelmann $G$. Platelet function in cardiac surgery: influence of temperature and aprotinin. Ann Thorac Surg 1993; 55 : 652-8.

34 Murkin JM, Lux J, Shannon NA, et al. Aprotinin significantly decreases bleeding and transfusion requirements in patients receiving aspirin and undergoing cardiac operations. J Thorac Cardiovasc Surg 1994; 107: 554-61.

35 Bertrand P, Mazzucotelli JP, Loisance D, Elsayed A, Deleuze $P$, Cachera JP. Laprotinine en chirurgie cardiaque chez les patients sous antiagrégants plaquettaires. Arch Mal Coeur Vaiss 1993; 86: 1471-4.

36 Murkin JM, McKenzie FN, White S, Shannon NA. A randomized comparison of the efficacy of high or low dose aprotinin, or tranexamic acid, to decrease blood loss and transfusion requirements in aspirin-treated cardiac surgical patients. Can J Anaesth 1994; 41: A33.

37 Isetta C, Samat C, Kotaiche M, Jourdan J, Grimaud D. Low dose aprotinin or tranexamic acid treatment in cardiac surgery. Anesthesiology 1991; 75: A80.

38 Hamilton A, Entwistle L, Koshal A, Finegan B. A randomized trial of aprotinin and tranexamic acid comparing their cost and effect on blood component use in repeat cardiac surgery (Abstract). Can J Cardiol 1993; 9 (Suppl E): $117 \mathrm{E}$.

39 Murkin JM, McKenzie FN, White S, Shannon NA. Blood loss in patients undergoing repeat median sternotomy randomized to either high or low dose aprotinin, or tranexamic acid. Can J Anaesth 1994; 41: A46.

40 Tatar H, Cicek S, Demirkilic U, et al. Topical use of aprotinin in open heart operations. Ann Thorac Surg 1993; 55: 659-61.

41 Goodnough LT, Johnston MFM, Toy PTCY, and the Transfusion Medicine Academic Award Group. The variability of transfusion practice in coronary artery bypass surgery. JAMA 1991; 265: 86-90.

42 Cosgrove DM III, Heric B, Lytle BW, et al. Aprotinin therapy for reoperative myocardial revascularization: a placebo-controlled study. Ann Thorac Surg 1992; 54: 1031-8.

43 Qurum E, Holen EA, Abdelnoor M, Oystese R, Lindstein Ringdal $M$. Tranexamic acid (Cyclokapron) is not necessary to reduce blood loss after coronary artery bypass operations. J Thorac Candiovasc Surg 1993; 105: 78-83.

44 Najman DM, Walenga JM, Fareed J, Pifarré R. Effects of aprotinin on anticoagulant monitoring: implications in cardiovascular surgery. Ann Thorac Surg 1993; 55: 662-6.

45 Sundt TM III, Kouchoukos NT, Saffitz JE, Murphy SF, Wareing TH, Stahl DJ. Renal dysfunction and intravascu- lar coagulation with aprotinin and hypothermic circulatory arrest. Ann Thorac Surg 1993; 55: 1418-24.

46 Bidstrup BP, Underwood SR, Sapsford RN. Effect of aprotinin (Trasylol) on aorta-coronary bypass graft patency. J Thorac Cardiovasc Surg 1993; 105: 147-53.

47 Lemmer JH Jr, Stanford W, Bonney SL, et al. Aprotinin for coronary bypass operations: efficacy, safety, and influence on early saphenous vein graft patency. J Thorac Cardiovasc Surg 1994; 107: 543-53.

48 Havel $M$, Grabenwöger $F$, Schneider $J$, et al. Aprotinin does not decrease early graft patency after coronary artery bypass grafting despite reducing postoperative bleeding and use of donated blood. J Thorac Cardiovasc Surg 1994; 107: 807-10.

49 Bidstrup BP, Harrison J, Royston D, Taylor KM, Treasure T. Aprotinin therapy in cardiac operations: a report on use in 41 cardiac centers in the United Kingdom. Ann Thorac Surg 1993; 55: 971-6.

50 Scott WJ, Kessler R, Wernly JA. Blood conservation in cardiac surgery. Ann Thorac Surg 1990; 50: 843-51. 